to the Geological Magazine in July 1872, but it was not so fortu. nate as to meet with acceptance from the editor. The following extracts coincide singularly with the opinions of Prof. Stanley Jevons :-

The river Rauma, at the western end, which gives its name to Romsdal, is the natural outlet. The outlet to the river Logen, at the eastern end, is entirely arlificial. The water-parting there, between Romsdal and the Dovre Feld, is an ancient ridge of drift. A cut has been made by man through this ridge. The stream through this cut now works a saw mill, but was formerly connected with the old iron works. The one outlet from the lake enters the mill pool, from which there are two outlets, one to serve the mill the other for the waste water. All these three outlets are kept each at its required level artificially, that is, with piles, logs, boulders, and rubble, so that the quantity of water which is let out of the lake is regulated by 'the miller and his men.' The case is precisely equivalent to the Black Loch, in Dumfriesshire, whose natural (!) outlet is an iron sluice in a stone dam opening to a mill lead cut through the water-parting to Lord Bute's mill. (See Athencum, Aug. 6, 1864 , and $25 \mathrm{in.}$ Ordnance maps.) If such lakes as these are lakes with two outlets, then the new conduit for the water supply of Glasgow makes Loch Katrine a lake with two outlets. An old dry channel is in direct continuation of the present mill lead. It passes so close to the old iron work as actually to touch its base. If, as I imagine (as does also Prof. Stanley Jevons), the two are connected with each other in origin, the artificial outlet to the lake may be of very great antiquity.

$\Lambda$ notice in NATURE, of a new work by Capt. Burton (1872), quotes these words of his: "The northern and north-western portions of the so-called 'Victoria Nyanza' must be divided into three independent broads or lakes. . . in order to account for the three effuents, within a little more than sixty miles." Here, then, the great traveller adopts my dictum, that "a lake can only have one outlet." I first published this dictum in the Athcnazm, July 4, 1863, when the late lamented Capt. Speke, in his "Sketch MIap," gave four outlets to Lake Victoria Nyanza, three on "native information;" and in the Athencum, July 25, I said, "I think that the native information will prove to be erroneous."

Brookwood Park, Alresford, Aug. 15

As Prof. Jevons has revived the question of the existence of lakes possessing more than one outlet, I would invite the attention of your readers to what appears to me an unequivocal instance of the kind, though on a small scale, in the neighbour. hood of the place whence I write.

On the high and very broken ground between the old mountain road from Dolgelly to Towyn (which runs at the foot of Cader Idris) and the south shore of the estuary of the Mawddach is a watershed, which separates streams flowing directly into the estuary by Capel Arthog from others which, after joining the stream that descends from Llyn y Gader in the hollow immediately under the summit of Cader Idris, find their way into the estuary some thrce miles higher up. On this watershed lies a Iake about half-a-mile long, named Llyn Creigenen, which occupies a rock basin with two lips at exactly the same level, one at its western, the other at its eastern extremity. By the western lip a small stream issues which descends rapidly and at one part of its course forms one of the branches of the Falls of Arthog, well known to visitors at Barmouth. By the eastern lip also, a stream, diminutive, it is true (at any rate in the summer months), but still quite distinct, issues and descends into a boggy tract, along which it wanders for some two miles, until it joins the stream before mentioned from Llyn y Gader. These facts are distinctly recorded on the Ordnance map, and I have frequently verified them myself and pointed them out to others. I think there can be no doubt but that in this instance both of the outlets are natural, and that a stream must issue from one if a stream Issues from the other, at any rate at the ordinary level of the water in the lake. It is perhaps, impossible to say that both outlets are permanent in that secular sense which Prof. Jevons seems to attribute to the word, as circumstances are easily conceivable under which the flow through the smaller easterly outlet might cease; but at any rate for many years, supposing the average supply of water to the lake to remain the same, and no artificial barrier to be erected, the two streams will continue to issue from the lake at all seasons.

Prof. Jevons remarks that " on i priori grounds it seems very unlikely that there should exist any lake with two distinct outflows." I would reply that, while it is undoubtedly improbable that any particular lake named at random should possess this characteristic, it can hardly be regarded as $d$ priori very unlikely that among all the lakes on the earth's surface there should be found here and there one with more than a single outlet. At any rate, I would recommend anyone who is sceptical in the matter to visit Llyn Creigenen, which is but an easy hour's walk from the Arthog Station on the railway between Barmouth Junction and Dolgelly.

Capel Arthog, Aug. 16 ROBERT B. HAYWARD

\section{Cranes in the Gardens of the Zoological Society of London}

In NATURE of June 26 (antea, p. 164), Mr. IV. A. Forbes points out an error in the report of the meeting of the Zoological Society for June I 5, in a statement that no example of Grus vipio (siz'e leucauchen) had been brought to Europe previously to those lately received by that Society. Instead of "Europe" the word "England" should have stood in the paragraph in question, which would then have been correct.

It is quite true (as stated by Mr. Forbes) that the collection of living cranes in the Gardens of the Zoological Society of Amsterdam is the fincst in the world. At the same time the series of these birds in the Regent's Park is also at the present moment very nearly perfect, embracing, as it does, examples of all the usually recognised species, with the exception of Grus leucogeramus, and G. monacha.

Of the former of these the Society once possessed a living specimen, but the rare $G$. monacha of Japan has, I believe, never yet reached Europe alive.

The following is a list of the Zoological Society's present series of the Gruidx: -2 Common Cranes (Grus cincria), i Brown Crane ( $G$. cantadensis), 2 White-necked Cranes ( $G$. leucauchens), I Sarus Crane (G. torquata), I Australian Crane (G.anstralasianta), I White American Crane (G. americana), I Mantchurian Crane (G.montignesia), 2 Wattled Cranes (G. carunculata), I Balearic Crowned Crane (Balearica pazonina), 4 Cape crowned Cranes (B. regulorum), 3 Demoiselle Cranes (Anthropoides virgo). August 27 P.L.S.

\section{Colour of Lightning}

I sIoutD be much obliged to any of your readers who would give me any information as to the cause of the colour of lightning.

In one of two storms which passed over here yesterday evening the lightning was decidedly pink in tint; later in the night it had regained its normal yellow or bluish colour.

Odrey, Aug. 25

H. GEORGE FORDHAM

\section{Harmonic Causation and Harmonic Echoes}

IN reference to the question of "Harmonic Echoes," allow me to suggest to those who may have the opportunity of observation, how desirable it is that these echo-tones should be investigated in a manner to determine whether they are truly harmonic or not. There would be no difficulty in testing the sounds given in response to the notes of a closed organ-pipe and an open one, or the notes of representative musical instruments, clarionet and flute. It might be found that the echo at Bedgebury Park would give the octave always, irrespective of the particular instrument provoking it; or, on the other hand, that it refused to answer to a closed pipe, or gave only the twelfth, its proper reply. We should then know whether the echo-tone was that of the harmonic or a new fragmental tone consequent on the breaking up of the wave of the fundamental or ground. tone, by "breakers ahead."

Now that we are called upon to recognise several varieties or classes of musical tone, it is time that the leaders in Science came to a general agreemeut upon the use of the term "har. monic." Is it to be applied indifferently to "over-tones," other. wise "partial-tones," to "combination-tones," to " concussion. tones," arising from the violence of the shock of sound-waves in collision, to "fragmental-tones" produced out of the wave of the ground-tone broken up by obstacles encountered in its course or in reflection, and to "echo-tones" which may be affiliated to either variety? It seems to me that we risk much confusion unless "harmonic" is restricted to its earlier usage, and applied solely to the "harmonic series,"-the tones which are the direct offshoots of the fundamental, These tones have but one order of succession, and will bear no interpolation: the 